\title{
Marcin Walkowiak
}

(Adam Mickiewicz University, Poznań)

https://orcid.org/0000-0001-7716-5813

\section{Graeco opere in Władysław Jagiełło’s Royal Power Theatre. Introduction to the Study}

\author{
Graeco opere w królewskim teatrze władzy Władysława Jagiełły. \\ Wprowadzenie do badań
}

\begin{abstract}
The Polish King Władysław II Jagiełło requested the creation of a set of Byzantine wall paintings, described by the historian Jan Długosz as graeco opere, pictura graeca or sculptura graeca. The paintings were located in places of particular political and religious significance for the Kingdom of Poland. Byzantine painting decoration was thoughtfully adapted to Gothic interiors.

The scientific reflection on Jagiellonian polychromes, conducted for over 150 years, still does not give full clarity as to the reasons for this unique artistic synthesis. Given the current state of knowledge about the role of art in the Middle Ages, the concept of the King's private predilection for Byzantine-Ruthenian painting, well established in the Polish medieval studies, is no longer convincing.

The author of this paper believes that this issue calls for new questions and a fresh research perspective. The study analyses the paintings in question in the context of the backdrop of the King's political theology and the importance of art in shaping the image of the monarch in the Late Middle Ages. On the basis of the latest historical research, the author presents King Władysław II Jagiełło primarily as an effective ruler and competent politician rather than an art enthusiast.
\end{abstract}

Key words: Byzantine-Ruthenian paintings, graeco opere, Władysław Jagiełło, Jagiellonians, Jagiellonian art

In his Annales, Jan Długosz writes about wall paintings commissioned by the Polish King Władysław Jagieło. The historian uses the terms graeco opere, pictura graeca or sculptura graeca, which suggests that they were ex- 
ceptional to a significant extent ${ }^{1}$. According to the sources, these paintings were to be found in the entire Kingdom of Poland. Some have survived to this day to greater or lesser extent. The frescoes in the Holy Trinity Chapel at the Lublin castle are in nearly pristine condition. Paintings in the presbytery of the Sandomierz cathedral and the presbytery of the collegiate church in Wiślica are not unspoiled. The ones in the St. Mary's chapel at the Wawel cathedral, in turn, are in a deplorable state ${ }^{2}$. Other sources mention similar paintings in the monastery church on Łysa Góra ${ }^{3}$, in the presbytery of the cathedral in Gniezno ${ }^{4}$, in the Chapel of the Holy Trinity at the Wawel cathedral ${ }^{5}$ and in the royal bedroom in the Wawel Castle 6 . Surely, it must have been a large group of paintings. What is important, however, is that they were created in places which were crucial for the exercise of royal power by the first Jagiellonians. The Byzantine decoration was skillfully adapted to the Gothic interiors. Although the medieval Europe did see similar syntheses using Byzantine elements in the broad definition of the term, they were rarely of that scale ${ }^{7}$. A comparable undertaking was

1 J. Dlugossi, Annales seu Cronicae incliti Regni Poloniae, lib. XI et XII, Varsaviae 2001, pp. 125-126; idem, Liber beneficiorum dioecesis Cracoviensis, vol. 3, ed. A. Przeździecki, Cracoviae 1864, pp. 229-230; idem, Liber beneficiorum, vol. 1, p. 264.

2 A. Różycka-Bryzek, Malowidła ścienne bizantyńsko-ruskie, in: Malarstwo gotyckie w Polsce, vol. 1: Synteza, eds. A. Labuda, K. Secomska, Warszawa 2004, pp. 155-184.

3 Rachunki dworu króla Władystawa Jagietty i królowej Jadwigi (1388-1420), ed. F. Piekosiński, Kraków 1896, pp. 156, 164, 192, 197, 202, 203; J. Dlugossi, Liber beneficiorum, vol. 3, pp. 229-230.

4 J. Dlugossi, Annales, lib. XI et XII, pp. 125-126; S. Damalewicz, Series archiepiscoporum Gnesnensium, Varsaviae 1649, p. 28.

5 A. Różycka-Bryzek, Niezachowane malowidła 'graeco opere' z czasów Władysława Jagietty, 'Analecta Cracoviensa' 1987, 19, pp. 303-304.

6 Rachunki dworu, pp. 202, 211; it may be inferred from the source material that Władysław Jagiełło might have also commissioned graeco opere in the region of Sieradz. Further work needs to be done in order to established whether and where it was performer. It might be reasonable to agree with the suggestion made by Leszek Kajzer, who believes the paintings could have been placed in the Holy Trinity Chapel at the Sieradz Castle, see Zbiór dokumentów małopolskich, eds. I. Sułkowska-Kurasiowa, S. Kuraś, part 7, Wrocław 1975, pp. 204-205; L. Kajzer, Gdzie w Sieradzkiem działali ruscy malarze Władysława Jagietty?, 'Kwartalnik Historii Kultury Materialnej' 2001, 4, pp. 387-394; see also, T. Olszacki, Zamek królewski w Sieradzu. Dzieje - badania - architektura, Sieradz 2013, pp. 27-30; the graeco opere decoration which can be still seen in the Holy Cross Chapel at the Wawel cathedral is the only work implemented under Jagiełło's successor, commissioned by Casimir IV Jagiellon and Elizabeth of Austria. See A. Różycka-Bryzek, Bizantyjsko-ruskie malowidła ścienne w Kaplicy Świętokrzyskiej na Wawelu (1470), 'Studia do Dziejów Wawelu' 1968, 3, pp. 175-287.

W.D. Wixom, Byzantine Art and the Latin West, in: The Glory of Byzantium. Art and Culture of the Middle Byzantine Era, A. D. 843-1261, eds. H.C. Evans, W.D. Wixom, New York 1997, pp. 434-450. 
made in the $12^{\text {th }}$-century Sicily, conquered by Normans at the time. Byzantine mosaic decorations were created inside four Norman churches ${ }^{8}$. Yet the number of royal orders in the Kingdom of Poland was much higher. It must have been of great importance for the client, judging by the effort made to implement the original idea as well as by the rank of the objects. That is why to understand the originator may be vital for our understanding of the role of art at the time of the first Jagiellonians. Researchers have been studying the Jagiellonian polychromes for over 150 years, yet they are undecided as to the reasons for this particular artistic concept and its function ${ }^{9}$. There are doubts concerning the name itself. In the scientific discourse, the term 'Byzantine-Ruthenian' was coined for the paintings and popularized by Anna Różycka-Bryzek in her numerous publications. It was her that recognised the style of the polychromes in the Holy Trinity Chapel in Lublin and determined the artists' background ${ }^{10}$. For years, Anna Różycka-Bryzek ${ }^{11}$ spread the idea that it was the King Władysław Jagiełło's particular aesthetic taste and fondness of Byzantine painting that was at the root of the paintings. She based it on the opinion of Jan Długosz, who described the 'Life, customs and defects of King Jagiełł' in his annals: '[...] Gnesnesnem, Sandomiriensem et Wislicensem ecclesias sculptura Graeca (illam enim magis quam Latinam probabat) adornavit ${ }^{12}$. ['decorated the churches in Gniezno, Sandomierz and Wiślica with Greek sculpture (because he liked it more than Latin art)' $]^{\prime 13}$. The assumption

8 E. Borsook, Messages in Mosaic. The Royal Programmes of Norman Sicily 1130-1187, New York 1990.

9 A. Różycka-Bryzek, Zarys historyczny badań nad bizantyńsko-ruskimi malowidłami ściennymi w Polsce, 'Biuletyn Historii Sztuki' 1965, 27, pp. 291-294; M. Walczak, Jagiellonowie a sztuka, in: Europa Jagiellonica 1386-1572. Sztuka, kultura i polityka w Europie Środkowej za panowania Jagiellonów. Materiały sesji zorganizowanej przez Zamek Królewski w Warszawie Muzeum i Instytut Historyczny w Warszawie, eds. P. Mrozowski, P. Tyszka, P. Węcowski, Warszawa 2015, p. 154; idem, Patronat artystyczny Jagiellonów, in: Patronat artystyczny Jagiellonów, eds. M. Walczak, P. Węcowski, Kraków 2015, pp. 11-12.

10 A. Różycka-Bryzek, Bizantyńsko-ruskie malowidła w kaplicy zamku lubelskiego, Warszawa 1983.

11 Zob. Bibliografia prac Anny Różyckiej-Bryzek, ed. M. Smorąg-Różycka, in: Ars Graeca Ars Latina. Studia dedykowane prof. Annie Różyckiej-Bryzek, ed. M. Smorąg-Różycka, Kraków 2001, pp. 17-22.

12 J. Dlugossi, Annales, lib. XI et XII, pp. 125-126.

13 A. Różycka-Bryzek, Bizantyńsko-ruskie malowidła w Polsce wczesnojagiellońskiej. Problem przystosowań na gruncie kultury łacińskiej, in: Polska - Ukraina: 1000 lat sasiedztwa, vol. 2, ed. S. Stepień, Przemyśl 1994, pp. 323-324; idem, Malowidła ścienne, pp. 155-160; J. Długosz, Roczniki czyli Kroniki stawnego Królestwa Polskiego, vol. 11-12: 1431-1444, Warszawa 2009, p. 142; the first researcher to study Jagiełło's personal inclination to Eastern art, Józef Muczkowski wrote in a publication on the Holy Cross and the Holy Trinity chapels at the Wawel Cathedral: 'The culture Rus had had an influence on both King Jagiełło and his wife 
regarding the artistic preferences of the founder of the Jagiellon dynasty has become well-established and is still being promoted ${ }^{14}$. A recent study on the rule of the Jagiellonian dynasty in Poland emphasises that King Władysław Jagiełło 'was a great lover of Byzantine-Ruthenian music and painting ${ }^{\prime 15}$.

It seems peculiar that the creation of wall paintings on such an extensive scale located in places of ideological importance for the Kingdom of Poland resulted merely from the King's private aesthetic taste. Art commissioned by monarchs in the Middle Ages were typically an important part of communicating the most important points of their political programmes ${ }^{16}$.

Zofija, a Ruthenian princess, as well as their son Casimir. Hence this predilection of theirs for the Greek painting style, referred to as mosaico or graeco more in official documents', see J. Muczkowski, Dwie kaplice jagiellońskie w katedrze krakowskiej, Kraków 1859, p. 21; M. Sokołowski linked the Ruthenian painting commissions with Jagiełło's personal liking 1880s, see M. Sokołowski, Malarstwo ruskie, in: Wystawa archeologiczna polsko-ruska we Lwowie 1885 r., Lwów 1885, p. 15.

14 See e.g. K. Biedrowska-Ochmańska, J. Ochmański, Władysław Jagiełło w opiniach swoich współczesnych. Próba charakterystyki jego osobowości, Poznań 1987, pp. 63-64; J. Krzyżaniakowa, J. Ochmański, Władysław II Jagiełło, wyd. 2 uzupełnione, Wrocław 2006, pp. 351-352; M. Smorąg-Różycka, Anna Cylejska - zapomniana patronka bizantyńskich malowideł w prezbiterium katedry pw. Wniebowzięcia Najświętszej Marii Panny w Sandomierzu, in: Patronat artystyczny Jagiellonów, pp. 289, 303.

15 U. Borkowska, Dynastia Jagiellonów w Polsce, Warszawa 2011, p. 479; a remarkable historical study with a versatile take on the royal activity of the Jagiellon dynasty. The author adheres to the idea of Jagiełło's personal preference for Orthodox painting; see also Marek Walczak's commentary on the issue of art in historical monographs, M. Walczak, Jagiellonowie a sztuka, p. 131.

16 There is a vast amount of literature on this matter, to list only several works on the use of art by Central European monarchs in the Late Middle Ages: P. Mrozowski, Sztuka jako narzędzie władzy królewskiej w Polsce, in: Dzieło sztuki: źródło ikonograficzne, czy coś więcej? Materiaty sympozjum XVII Powszechnego Zjazdu Historyków w Krakowie, 15-18 września 2004, ed. M. Fabiański, Warszawa 2005, pp. 67-78; M. Kutzner, Propaganda władzy w sztuce Zakonu Niemieckiego w Prusach, in: Sztuka w kręgu zakonu krzyżackiego w Prusach i Inflantach, ed. M. Wodniak, Torun 1995, pp. 17-66; M. Walczak, Power and History. The Past as a Means of Legitimacy a Ruler's Authority in the Court art of Fourteen Century Poland, 'Uměni' 2014, 62, pp. 2-16; idem, Casimir the Great's Artistic Foundations and the Court art of the Luxembourgs, in: Kunst als Herrschaftsinstrument. Böhmen und das Heilige Römische Reich unter den Luxemburgenim Europäischen Kontext, eds. J. Fajt, A. Langer, Berlin-München 2009, pp. 534549; I. Rosario, Art and Propaganda: Charles IV of Bohemia, 1346-1378, Woodbridge 2000; P. Crossley, The Politics of Presentation. The Architecture of Charles IV of Bohemia, in: Courts and Regions, eds. R. Marks, A. Minnis, York 2000, pp. 99-172; J. Fajt, Charles IV. Toward a New Imperial Style, in: Prague. The Crown of Bohemia, 1347-1437, eds. B. Drake Boehm, J. Fajt, New York 2005, pp. 3-23; B. Czechowicz, M. Kapustka, Hope and Pragmatism. The Rule and Visual Representation of Matthias Corvinus in Silesia and Lusatia, in: Matthias Corvinus, the King. Tradition and Renewal in the Hungarian Royal Court 1458-1490, Budapest 2008, pp. 77-89; A.S. Labuda, Die architektonische Gestalt der Trinitäts - und der Heiligkreuzkapelle an der Krakauer Kathedrale im Kontextköniglischen Residenz auf dem Wawel, in: Die Länder der 
Similar practices had occurred in Poland before, e.g. during the reign of Casimir the Great ${ }^{17}$. It is, therefore, unclear why Władysław Jagiełło should be perceived differently. He was a seasoned politician who implemented his plans consistently and achieved his goals. Describing his character, the authors of the King's biography, Jadwiga Krzyżaniakowa and Jerzy Ochmański, emphasize that 'Politics was his element. He never acted on his emotions, but always by the raison d'État. He tried to achieve the goal and pay the lowest price. When it required sacrifices or a change in tactics, he did not shy away from unpleasant but firm measures. He was able to properly assess the situation and choose the right path. He was a generous ruler, but it was absolutely impossible to trust him. He moved with the times, entered agreements at the right time and withdrew from them when he felt it was necessary' ${ }^{18}$. The King's experts and advisors played an important role in his political undertakings. The royal court included those responsible for creating his image as a Christian monarch and the successor of Piasts on the Polish throne ${ }^{19}$. With the current state of knowledge about the role of art in the Middle Ages, the popular idea of Jagiełło's predilection for Orthodox painting, supposedly rooted in his family home, is not convincing as the alleged primary motive behind the creation of the graeco opere.

böhmischen Krone und Imre Nachbarn zur Zeit der Jagiellonenkönige (1471-1526). Kunst, Kultur, Geschichte, Ostfildern 2004, pp. 69-83.

17 P. Mrozowski, Sztuka jako narzędzie władzy. Patronat artystyczny Kazimierza Wielkiego, in: Sztuka i władza. Materiaty z konferencji zorganizowanej przez instytut PAN w dniach 30.XI2.XII 1998, eds. D. Konstantynow et al., Warszawa 2001, pp. 5-14; M. Walczak, Rzeźba architektoniczna w Małopolsce za czasów Kazimierza Wielkiego, Kraków 2006, pp. 348-405.

18 J. Krzyżaniakowa, J. Ochmański, op. cit., p. 139; see also, K. Biedrowska-Ochmańska, J. Ochmański, op. cit., pp. 7-8; J. Nikodem, Jadwiga. Król Polski, Wrocław 2009, p. 287.

19 J. Krzyżaniakowa, J. Ochmański, op. cit., p. 314; J. Krzyżaniakowa, Kancelaria królewska Władysława Jagiełty. Studium z dziejów kultury politycznej Polski w XV wieku, vol. 1/2, Poznań 1972; idem, Polska - antemurale christianitatis - polityczne i ideologiczne podstawy kształtowania się idei, in: Docendo Discimus. Studia historyczne ofiarowane Zbigniewowi Wielgoszowi w siedemdziesiata rocznice urodzin, eds. J. Kaczmarek, J. Nikodem, Poznań 2000, pp. 301-303; K. Ożóg, Jagiellonowie a uczeni, in: Europa Jagiellonica, pp. 119-123; idem, Miejsce $i$ rola uczonych w późnośredniowiecznym państwie polskim. Poglady mistrzów krakowskich a rzeczywistość, in: Genealogia. Władza i społeczeństwo w Polsce średniowiecznej, eds. J. Wroniszewski, A. Radzimiński, Toruń 1999, pp. 271-301; W. Fałkowski, Idea monarchii w Polsce za pierwszych Jagiellonów, in: Polska około roku 1400. Państwo, społeczeństwo, kultura, ed. W. Fałkowski, Warszawa 2001, pp. 210-211; K. Baczkowski, 'Panowie przyrodzeni' a elekcyjność tronu w Polsce średniowiecznej, in: idem, Polska i jej sassiedzi za Jagiellonów, Kraków 2012, pp. 36-38; P. Węcowski, Dwa przyczynki do piastowskiej legitymizacji władzy Jagiellonów. Imiona i liczebniki w tytulaturze polskich Jagiellonów, in: Świat średniowiecza. Studia ofiarowane Profesorowi Henrykowi Samsonowiczowi, eds. A. Bartoszewicz i inni, Warszawa 2010, pp. 562-576. 
Researchers have repeatedly pointed out that this thesis is unsupported and weak. They have formulated alternative proposals which would explain why the King would invite painters from another culture. It has been suggested that he wanted to employ artists with better technical skills due to the lack of properly trained local painters ${ }^{20}$. Another proposal holds that the presence of paintings by artists from Rus was a natural process where artistic solutions from neighbouring territories penetrated the Kingdom of Poland. Jagiełło's patronage was only to intensify this phenomenon ${ }^{21}$. It may also have been related to the plans of unifying the Churches in the areas ruled by Władysław Jagiełło ${ }^{22}$. Tadeusz M. Trajdos, who came up with this idea, argues that the Jagiellonian paintings are perhaps a remnant of an attempt to develop a 'new painting formula corresponding to royal thought - the idea of uniting Churches which speak the language of both civilizations $^{23}$. In an article on the function of the collegiate church in Wiślica in the 14th and 15th century, Wojciech Drelicharz suggests that the polychrome should be seen as part of the King's self-promotional strategy. The paintings in the collegiate were to show the specificity of the cultural area that the monarch intended to include in the area of influence of the Kingdom of Poland ${ }^{24}$. Grażyna Jurkowlaniec believes in turn that Russian paintings should be analysed in juxtaposition to other works of art Jagiełło funded, especially with the tomb of the King. According to her studies,

20 W. Podlacha, Malarstwo średniowieczne, in: Historia malarstwa polskiego, vol. 1, Lwów 1914, pp. 85-114.

21 M. Walicki, Malowidła ścienne kościoła św. Trójcy na zamku w Lublinie, 'Studia do Dziejów Sztuki w Polsce' 1930, vol. 3, p. 2; Walicki holds that the phenomenon intensified as a result of Jagiełło's preferences 'rooted in his upbrining' see ibidem; Wojsław Molè and Anna Marsówna supported the idea that art naturally propagated from the Balkans and various areas of the Rus to the Kingdom of Poland, see W. Molè, Kilka uwag o malowidtach ściennych w Wiślicy, 'Ochrona Zabytków Sztuki' 1930-1931, 1-4, pp. 98-102; idem, Sztuka bizantyńsko-ruska 1040-1500, in: Historia sztuki polskiej, vol. 1, Kraków 1962, pp. 185-186; A. Marsówna, Freski ruskie w katedrze sandomierskiej, 'Prace Komisji Historii Sztuki' 19301934, 5, pp. 20-23.

22 C. Osieczkowska, O szkole polskiej malarstwa bizantyńskiego, 'Prace i materiały sprawozdań sekcji historii sztuki' 1935, vol. 2, pp. 35-130; Cz. Deptuła, Z zagadnień relacji pomiędzy sztuka, polityka i programami unii kościelnej w państwie polsko-litewskim XV wieku, 'Summarum' 1995/1996, vol. 24/25, pp. 133-142.

23 T.M. Trajdos, Treści ideowe i kręgi stylistyczne polichromii bizantyńskich w Polsce za panowania Władysława II Jagiełty (1386-1434), 'Zeszyty Naukowe Wydziału Humanistycznego Uniwersytetu Gdańskiego. Slawistyka' 1982, 3, pp. 164; see also A. Różycka-Bryzek, Uwagi o referacie T. M. Trajdosa pt. Treści ideowe wizerunków Jagiełty w kaplicy św. Trójcy na zamku lubelskim, 'Biuletyn Historii Sztuki' 1980, 42, 3/4, p. 438.

24 W. Drelicharz, Kolegiata wiślicka jako miejsce wizualnego dialogu monarchy ze społeczeństwem w XIV-XV wieku, in: Przeszłość jest czasem narodzin. Z dziejów Wiślicy i jej związków z Krakowem, eds. A. Waśko, J. Smołucha, Kraków 2006, p. 56. 
the artistic patronage of the King did not focus on the aesthetic side of the commissions, but rather on presenting him effectively as a continuator of the political legacy of the last Piast. Therefore, she believes, the context of the previous commissions of Casimir the Great is crucial to understand what the paintings actually were ${ }^{25}$.

Given years of research which prioritises source examination, this paper favours the approach whereby the graeco opere commissioned by Władysław Jagiełło were closely related to his political programme and constituted an important part of creating his political image. The sources indicate that the graeco opere decorations which have not survived to present day require particular attention as they are the key to interpreting the entire phenomenon. Until now, the focus was primarily on the preserved works, whereas the source information concerning the destroyed paintings was only mentioned selectively and out of research duty ${ }^{26}$. As a result, scholars overlooked many important hints which could help explain the question of Jagiellonian frescoes. Researchers' findings which regard the manner Władysław Jagiełło administered his kingdom, including his regular tours around the country ${ }^{27}$, are particularly useful. The locations of the graeco opere paintings were among the most important on the route of royal journeys. According to Jagiello's Itinerarium compiled by Antoni Gąsiorowski, the King repeatedly visited the places where the churches decorated with graeco opere paintings were located: Sandomierz - 64 times; Wiślica - 42 times; Lublin - 35 times; Gniezno - 30 times; Święty Krzyż -11 times $^{28}$. Furthermore, these places were associated with the oldest

25 G. Jurkowlaniec, The Artistic Patronage of Ladislaus Jagiełto. Beyond the Opposition between Byzantium and the Renaissance, in: Bizancjum a renesansy. Dialog kultur, dziedzictwo antyku. Tradycja i wspótczesność, ed. M. Janocha, Warszawa 2012, pp. 271-281.

26 Anna Różycka-Bryzek authored a paper on the graeco operae paintings which have not been preserved to date. It is, however, a concise and rather general list of the commissions, indication of the source material available and its preliminary analysis, see A. Różycka-Bryzek, Niezachowane malowidła 'graeco opere', pp. 295-317; the lost paintings of the Benedictine church in Łysa Góra were subject to a deeper analysis by Tadeusz Trajdos, see. T. Trajdos, Benedyktyni na Łyścu za panowania Władysława II Jagiełty (1386-1434), 'Rocznik Historyczny' 1982, 48, pp. 25-30.

27 A. Gąsiorowski, Itinerarium króla Władysława Jagietty 1386-1434, corrected and updated 2nd ed., Warszawa 2015; idem, Podróże panujacego w średniowiecznej Polsce, 'Czasopismo Prawno-Historyczne' 1973, 25, 2, pp. 41-67; P. Węcowski, Działalność publiczna możnowładztwa małopolskiego w późnym średniowieczu. Itineraria kasztelanów i wojewodów krakowskich w czasach panowania Władystawa Jagiełty (1386-1434), Warszawa 1998; idem, Polskie itineraria średniowieczne i nowożytne. Przegląd badań i propozycje badawcze, 'Studia Źródłoznawcze' 2000, 37, pp. 13-48.

28 A. Gąsiorowski, Itinerarium, pp. 126-143; Antoni Gąsiorowski argued that the king's travels were largely based on the liturgical year. The basis of the travel schedule was the Paschal cycle, determined by the date of Easter. The king participated in the ceremonies 
political and religious traditions of the Piast dynasty ${ }^{29}$. Their significance was so important that they were selected as the venue of sophisticated ceremonial acts in the 14th century and early 15th century (such as feudal tributes, major church ceremonies, coronation and funeral ceremonies, ceremonial liturgies which opened and closed the Crown Council meetings.). The King played a central role in those events, demonstrating the splendour of the royal power in the presence of the country's political elite and foreign parliamentarians ${ }^{30}$.

Another important issue which arises from the research yet is underestimated by researchers is the terminology. Jan Długosz refers to the paintings by means of three different terms: graeco opera, pictura graeca and

attended by the faithful of various social standing. Solemn liturgies performed in the most important churches were a combination of religious ceremonies with the secular teatrum ceremoniale aimed at presenting the majesty of ruler. Preserved documents issued by the royal office indicate that the king decided administrative and judicial matters while staying in a particular place. He held meetings with representatives of the political elite of the kingdom, congresses, courts and received foreign parliamentarians. As demonstrated by A. Gąsiorowski, it should be stressed that Jagiełło's model of royal journeys, based on the schedule of movable holidays, has not been applied by any other Polish rulers, but there is a number of similarities to emperors' itineraries; see A. Gąsiorowski, Święta pańskie w praktyce objazdów króla Władysława Jagiełty, in: Europa środkowa i wschodnia w polityce Piastów, ed. K. Zielińska-Melkowska, Toruń 1997, pp. 291301; idem, Itinerarium, pp. 154-162.

${ }^{29}$ Lublin was of importance for several reasons. Its political significance increased during Jagiello's reign due to its old Piast origins. It is, of course, also due to the geographical location of the city in respect of the communication routes between the Kingdom and the Grand Duchy of Lithuania. It was the centre of royal administration in this part of the kingdom as well as the venue of Polish-Lithuanian conventions. The particular value of Lublin and the unique role of this city could have been intended and devised, as it was in Lublin that Polish knights elected Jagiełło, the Grand Duke of Lithuania, as the King of Poland, during the congress of February 2, 1386. In the Middle Ages, such places were associated with the legal and ideological foundations of royal power and thus assigned special symbolic significance. In the Polish Kingdom, these were first and foremost Gniezno and Kraków as the venues of royal coronations; see Z. Dalewski, Władza, przestrzeń, ceremoniał. Miejsce i ceremonia inauguracji władzy w Polsce średniowiecznej do końca XIV wieku, Warszawa 1996; for the reasons for the growing importance of Lublin during the reign of Władysław Jagiełło see also, A. Sochacka, Zjazdy polsko-litewskie w Lublinie i Parczewie $w$ czasach Władysława Jagiełty, in: idem, Regimen - dominium - societas nobilium. Z dziejów gospodarki i polityki w Lubelskiem w średniowieczu, Lublin 2014, pp. 181-193; idem, Powody lokalizacji w Lublinie grunwaldzkiego wotum Wtadystawa Jagietty, in: ibidem, pp. 209-222.

30 A. Gieysztor, Spektakl i liturgia - polska koronacja królewska, in: Kultura elitarna a kultura masowa w Polsce późnego średniowiecza, Wrocław 1978, pp. 9-23; U. Borkowska, op. cit., pp. 229-260; idem, Codzienny i odświętny ceremoniat religijny na dworze Jagiellonów, in: Theatrum ceremoniale na dworze ksiażąt i królów polskich, eds. M. Markiewicz, R. Skowron, Kraków 1999, pp. 61-84;Z. Dalewski, Ceremoniał hołdu lennego w Polsce późnego średniowiecza, in: ibidem, pp. 31-44. 
sculptura graeca ${ }^{31}$. The late medieval sources which have been preserved to this day never describe the paintings as 'Ruthenian', although the painters themselves are called pictores Ruthenicos in court bookkeeping ${ }^{32}$. The terms used by Długosz are not accidental. The concept of graeco opere was used throughout the Middle Ages in Latin Europe in reference to icons, reliquaries and artistic objects imported from the Byzantine Empire $^{33}$. From the 13th century, icons originating from Byzantium (graeco opere) were frequently identified with 'venerable originals from legendary distant eras $^{\prime 34}$. Faith in archetypes coming from the Biblical lands through Byzantium was widespread ${ }^{35}$. Giordano da Rivalto, a Dominican monk active in Florence, preached in 1306 about the paintings he had brought from Greece. He credited them with an authority equal to the Holy Bible because the biblical figures are presented 'the way they really looked' ${ }^{36}$. In the same period, authors of art treatises from the fourteenth- and fifteenth-century Italy used the term graeco in order to emphasise the old, archaic, out-dated nature of the described work of art, in opposition to the modern (moderno) Latin painting of the early modern period ${ }^{37}$. Cennino Cennini, the author of a late- $14^{\text {th }}$-century treatise Libro dell'arte, wrote: ' $[. .$. Giotto rimutò l'arte del dipengere di greco in latino e ridusse al moderno $[. . .]^{\prime 38}$.

If the confusing terms occupied such a large semantic area, it becomes important to explain how these Byzantine paintings were received by Jagiello's contemporaries. It should be, however, borne in mind that the paintings commissioned by the King were installed in places of distinctive political and religious significance for the Kingdom of Poland. They were venues of festive ceremonies with the participation of the political elite of the Kingdom, as well as foreign deputies arriving in Poland from different regions of Europe ${ }^{39}$. As an art patron, Władysław Jagiełło's

31 See footnote no. 1; Annales of Jan Długosz underwent revision over the last decades, resulting in revised editions of lib. XI i XII Annales in Latin (2001) and translated to Polish (2004). In the entry for the year 1434, Długosz mentions sculptura graeca decorations commissioned by Jagiełło; see J. Wyrozumski, 55 lat badań nad krytyczna reedycja dziejów Polski Jana Dtugosza, 'Nauka' 2006, 2, pp. 153-166.

32 Rachunki dworu, pp. 202, 211.

33 H. Belting, Obraz i kult. Historia obrazu przed epoka sztuki, transl. T. Zatorski, Gdańsk 2010, pp. 376-380.

34 Ibidem, p. 376.

35 Ibidem, p. 379.

36 Ibidem, p. 351.

37 G. Jurkowlaniec, West and East perspectives on the 'Greek Manner' in the Early Modern Period, 'Ikonotheka' 2009, 22, p. 78.

38 Ibidem, p. 73.

39 The notion of 'political elites' is used here according to the experts on this issue. During the reign of the first Jagiellons, it denoted representatives of the nobility and the 
strategic objective was to present himself as the ideological successor of the last Piast ${ }^{40}$, while some of the paintings he commissioned from Eastern painters were placed in churches funded by Casimir the Great. Aleksandra Sulimierska-Gąska concluded that these paintings could be understood as objects representing the old eastern tradition, 'coming from the East', similar to icons, relics and other objects considered to have originated in Byzantium, Constantinople or even the Holy Land ${ }^{41}$.

Jan Długosz uses the word 'Greek' in significant situations. In Annales, he describes the beginnings of the Łysa Góra abbey before 1006 including the transfer of an Eastern reliquary in the story. The holy object was presented by the Hungarian prince Emeric to the Polish ruler Bolesław the Brave and contained a part of the Holy Cross. Długosz points out that the father of the guest, King Stephen I of Hungary, received the reliquary from Grecorum cesare ex Constantinopoli ${ }^{42}$. Długosz considered the origin of the reliquary an important piece of information, probably in order to the accentuate the authenticity of the relic and thus the unique value of its place of worship. The information about the origin of the relic must have been substantial for the historian because he mentions it again in Liber beneficiorum, describing the Greek emperor and the monastery church on Łysa Góra, where the relic is stored, and which was built in the opere vetusto et graeco style by Bolesław Brave and adorned with pictura graeca (Greek paintings) by King Władysław II. The chronicler ordered the described events chronologically, combining them by the common term graeco ${ }^{43}$. Years ago, Franciszek Mąkinia attempted to explain what Długosz meant by describing architecture with the terms graecorum more and opere graeco.

clergy who actively participated in public life and domestic politics. Within this group, higher clergy and members of cathedra and collegiate chapters played an important role; see M. Koczerska, Elita zjednoczonego Królestwa Polskiego w XIV-XV wieku i jej funkcja w państwie, in: Od genealogii do historii społecznej, eds. A. Jaworska, B. Trelińska, Warszawa 2011, pp. 11-25; D. Wróbel, Elity polityczne Królestwa Polskiego wobec problemu krzyżackiego w czasach Władysława Jagietty, Lublin 2017, pp. 16-21; z in respect of the issue under consideration, it is important to analyse the interactions between the elites and the monarch e.g. during various ceremonies; see W. Fałkowski, Możnowładztwo polskie wobec króla, in: Kolory i struktury średniowiecza, ed. W. Fałkowski, Warszawa 2004, pp. 9-22; idem, Adventus regis. Powrót Wtadystawa Jagietty do Krakowa po zwycięstwie grunwaldzkim, 'Roczniki Historyczne' 2010, 76, pp. 77-101; A. Gąsiorowski, op. cit., pp. 154-162; W. Drelicharz, op. cit., p. 56.

40 G. Jurkowlaniec, The Artistic Patronage, pp. 271-281.

41 A. Sulimierska-Gąska, At the Crossroads of Traditions. Ortodox Church Painting in the Reign of the Jagiellons, 'Ikonotheka' 2009, 22, p. 40.

42 J. Dlugossi, Annales, lib. I-II, Warszawa 1964, p. 256; J. Długosz, Roczniki, ks. 1-2, Warszawa 1962, p. 329.

43 J. Dlugossi, Liber beneficiorum, vol. 3, pp. 228-229. 
He concluded that these terms were a variation or specification of the term opus vetustum (ancient custom) with respect to architecture ${ }^{44}$. In relation to paintings commissioned by Jagiełło, according to Mąkinia, it could mean that the chronicler wanted to emphasize the Byzantine style of the works of $\mathrm{art}^{45}$. In his description of the monastery church on Łysa Góra, Długosz undoubtedly used the term opere graeco to highlight the antiquity of the object, but he might have wanted to emphasize the relationship between the building and the origin of the reliquary kept inside. If so, Długosz could have considered the decoration of the interior of the Łysa Góra temple, conceived by Władysław II Jagiełło and defined by the historian as pictura graeca, as an element intended to underline the history of the church and to evoke the origin of the relic. This reasoning is supported by another, later reference in which King Jagiełło requested that the lead roof of the Łysa Góra temple be made, on top of the paintings inside the church ${ }^{46}$. The old building was thus protected without any changes introduced to its architecture. It can be assumed that the point of decorating the interior of the old church with pictura graeca was to consolidate and accentuate the authenticity of the original architecture of the temple ${ }^{47}$. Even after the structure of the church was expanded in the mid-15th century, the oldest part of the temple was preserved intact, still decorated with Jagiello's paintings ${ }^{48}$. In the eighteenth century, forty years before the great fire of the church in 1777, it was remembered by Jacek Jabłoński, a Benedictine monk. He writes in Drzewo Żywota z Raju: '[...] The pious Monarch [Władysław Jagiełło] had the whole Church painted the Greek way, which still lasts to some point $[\ldots]^{\prime 49}$.

44 F. Mąkinia, Ocena estetyczno-stylistyczna polskiej architektury w twórczości J. Długosza, 'Roczniki Humanistyczne' 1971, 19, 5, pp. 37-38.

45 Franciszek Mąkinia adds that Długosz might have used the stylistic term graeco opere both with regard to architecture and paintings as a result of his pilgrimage to the Holy Land, 'which must have definitely been an encounter with genuine Byzantine architecture, much like in the case of the Ruthernian-Byzantine frescoes he saw multiple times e.g. in the Holy Trinity Chapel at the Lublin castle', see F. Mąkinia, op. cit., p. 38.

46 M. Sulimierska-Laube, Benedyktyński klasztor świętego Krzyża na Łyścu w okresie gotyckim, 'Biuletyn Historii Sztuki' 1963, 25, 3, p. 190.

47 In his analysis of different manners in which Długosz described past architecture, Piotr Gryglewski argues that the pictura graeca in the Łysa Góra church as mentioned in the Annales 'is close to exemplary renovation aimed at maintaining the previous style and decor', see P. Gryglewski, De Sacra Antiquitate. Odwołania do przeszłości w polskiej architekturze sakralnej XVI wieku, Warszawa 2012, p. 112.

48 The closter church in Łysa Góra was extended in Gothic style in 15th century by request of Casimir IV Jagiellon, see M. Sulimierska-Laube, op. cit., p. 191.

49 J. Jabłoński, Drzewo Żywota z Raju, Kraków: printed in the printing house of Jakub Matyszkiewicz 1737, p. 191. 
The significance of Byzantine paintings is also evidenced by the fact that Jan Długosz considered it important to mention them in his annals when summarizing the life and achievements of King Władysław II. To describe the ruler's relation to these paintings, the chronicler used the verb probo in the third person singular. In Book Eleven of the Annales, the said phrase reads: '[...] Gnesnesnem, Sandomiriensem et Wislicensem ecclesias sculptura Graeca (illam enim magis quam Latinam probabat) adornavit'50. It is interesting to note that it was translated as follows in the Polish edition: 'The churches in Gniezno, Sandomierz and Wiślica were decorated with Greek sculpture (as he liked it more than Latin) ${ }^{\prime 51}$. The verb probo means not only to like, but also to recognize, evaluate positively, consider credible ${ }^{52}$. With the meaning of the word probo narrowed down, Długosz's statement lost its original meaning ${ }^{53}$.

Jan Długosz might have used the word probo to emphasize the fact that Jagiełło commissioned the sculptura graeca paintings not because he liked them for their aesthetics, but because he cherished them more. He knew their value and authenticity. The decisions leading to the commissioning of paintings by Ruthenian artists in Łysa Góra were therefore probably not a result of personal taste or relatively sentimental choices. It could have been suggested by royal advisors, who recognised that such decorations would best represent the origin of the reliquary, i.e. Constantinople or the Byzantine Empire generally. It is also possible that the direct reason for this decision was the decoration of the Łysa Góra reliquary, most likely a Byzantine staurotheke ${ }^{54}$. The choice was made at the very beginning of

50 J. Dlugossi, Annales, lib. XI et XII, pp. 125-126.

51 J. Długosz, Roczniki, book 11-12, p. 142.

52 Stownik łaciny średniowiecznej w Polsce, vol. VII, 8, ed. K. Weyssenhoff-Brożkowa, Kraków 1998, pp. 1196-1197; see also Stownik łacińsko-polski, vol. IV, ed. M. Plezia, Warszawa 1974, pp. 299-300.

53 See footnote 32; I would like to thank Roma Lipońska for her philological advice and valuable suggestions

54 T. Trajdos, op. cit., pp. 21-22; M. Derwich, Benedyktyński klasztor św. Krzyża na Eysej Górze w średniowieczu, Warszawa-Wrocław 1992, pp. 243-244; On the topic of the hypothetical possibility that the staurotheke in Łysa Góra inspired the painting decoration of the temple, it is worth recalling the observations made by the researchers who studied the architecture of the Gothic Gniezno cathedral. There, the rich sculptural decoration of the cathedral's nave from the end of the 14th century supposedly refers to the border of the 12th-century bronze door depicting the Life of Saint Adalbert. The door was originally in the Romanesque cathedral and then transferred to the new Gothic building. As Jacek Kowalski comments, 'It seemed logical to extend the reliquary door decorations to the entire Gothic body, which became one great reliquary of St Adalbert as a result.' See J. Kowalski, Gotyk wielkopolski. Architektura sakralna XIII-XVI wieku, Poznań 2010, p. 75; see also A.S. Labuda, Porta regia. Drzwi gnieźnieńskie, Gniezno 1998, p. 25. 
Jagiełło's reign. Subsequent projects carried out in the same spirit show that the decision was comprehensive and important for building the King's image. The King's decision to introduce the pictura graeca in the Łysa Góra abbey church could have been influenced by abbot Mikołaj Drozdek, a close associate of the ruler. In 1386, Mikołaj Drozdek was the chaplain and confessor of Jagiełło. According to Marek Derwich, Drozdek, who became the abbot of the Benedictine monastery at Łysa Góra in 1380, most likely accompanied Jagiello before his baptism ceremony, and might have even participated in negotiations preceding the Union of Krewo. It is highly probable that he was a religious guide who introduced Jagiełło, a pagan, into the world of Christian spirituality. In Liber beneficiorum, Długosz refers to him as the regii praedicatoris et confessoris ${ }^{55}$. Abbot Mikołaj Drozdek could also be the King's advisor on the presentation of the royal cult of the Holy Cross, thus helping to build the Christian image of the monarch. If we were to consider these circumstances for the creation of the first Byzantine paintings - the ones in the Świętokrzyskie abbey church, then the subsequent works should be seen in a similar context. The graeco opere paintings commissioned by Jagiełł in selected buildings in the Kingdom of Poland could be seen as an integral part of his political image as a Christian ruler, defender of the Holy Cross, and the New Constantine, skilfully shaped by royal advisors. The last facet of the identity is particularly significant since the merits of Constantine the Great for Christianity and the Church were often remembered in the late Middle Ages. He was the model of a ruler ${ }^{56}$. A close associate and advisor of Władysław Jagiełło, Stanisław from Skarbimierz, the first rector of the Krakow Academy, set the role model of Emperor Constantine for a Christian monarch in his work entitled Speeches of wisdom ${ }^{57}$. Throughout the Middle Ages, people believed that Constantine the Great brought the relics of the Holy Cross to

55 Zob.J.Dlugossi, Liber beneficiorum, vol.3, p. 229; M. Derwich, Działalnośćbenedyktynów tysogórskich w XV wielu, 'Kwartalnik Historyczny' 1990, 3-4, p. 40; K. Bracha, Kult relikwii Krzyża św. i pielgrzymka Władystawa Jagietty do opactwa łysogórskiego w czerwcu 1410 r., in: Bitwa grunwaldzka w historii, tradycji i kulturze 1410-2010, ed. T. Ossowski, Kielce 2010, p. 8; In his collection of works on the Benedictine history in Poland, Paweł Szczaniecki OSB indicates that king Jagiełło referred to Abbot Mikołaj as 'beloved chaplain' and promoted him to the royal preacher and confessor, see P. Szczaniecki OSB, Benedyktyni polscy. Zbiór szkiców i opowiadań, Tyniec 1989, p. 139.

56 R. Chadraba, Tradice druhégo Konstantina a řecko-perská antiteze v uměni Karla IV., 'Uměni' 1968, 16, pp. 567-603; K. Kubínová, Karl IV. und die Tradition Konstantins des Grossen, in: Kunst als Herschaftsinstrumen. Böhmen und das Heiligerömische Reich unter den Luxemburgern im europäischen Kontext, Berlin-München 2009, pp. 320-327.

57 Stanisław ze Skarbimierza, Mowy wybrane o madrości, ed. M. Korolko, Kraków 2000, p. 133; K. Ożóg, Stanisław ze Skarbimierza - uczony w służbie Królestwa Polskiego, in: Przeszłość jest czasem narodzin, pp. 69-85. 
Constantinople, acknowledging them as an imperial symbol of power and a source of victory. The subsequent Byzantine emperors considered these relics as the palladium of the empire and gave rise to the tradition of funding imperial reliquaries in the form of staurothekes, regarded as a symbol and guarantee of triumph ${ }^{58}$. In this context, it is of extreme significance that Sigismund of Luxembourg compared Jagiełło to Emperor Constantine in a speech given at the Council of Constance in $1418^{59}$. Władysław Jagiełło's cult of the Łysa Góra relics was a part of a long medieval tradition linked directly to Emperor Constantine the Great. Jan Długosz mentions Jagiełło's pilgrimages to the Świętokrzyskie monastery as a proof of the exceptional implication of the place housing the Holy Cross particle in the Kingdom of Poland for its ruler ${ }^{60}$. The paintings of the Łysa Góra abbey church, the first of its kind made by 'Ruthenian' painters working on Jagiełło's commission, was probably related to the need for a special setting, which was important when building the image of the royal majesty in the place of worship. The decoration pictura graeca of Łysa Góra serve as a reference point for other works made by painters from Rus' invited by Władysław II $^{61}$. Furthermore, these decorations were an integral part of the symbolic message of the royal coat of arms, i.e. the Double Cross. According to Jagiellonian heraldry researchers, Jagiełło's coat of arms was probably inspired by the shape of the staurotheke of Łysa Góra ${ }^{62}$. Marek Derwich believes that it could have even been used during the coronation of Władysław Jagiełło in 1386 as an 'insignia item' ${ }^{63}$. The Piast coronation insignia ('insignia of Bolesław I the Brave') were taken to Hungary in 1370 by Louis of Hungary ${ }^{64}$. For this reason, the staurotheke of Łysa Góra was perceived as the only item in the Kingdom of Poland of such a high rank associated with the first king of Poland, Bolesław I the Brave. Maria

58 J. Pysiak, Król i korona cierniowa. Kult relikwii we Francji Kapetyngów, Warszawa 2012, pp. 121-122.

59 J. Caro, Aus der Kanzlei Kaiser Sigismundus. Urkundliche Beiträge zur Geschichte des Constanzer Concils, 'Archiv für Österreichische Geschichte' 1880, 59, p. 166.

60 J. Dlugossi, Annales, lib. XI et XII, p. 125; K. Bracha, op. cit., pp. 7-20.

61 For more information on the missing pictura graeca in Łysa Góra and its meaning see M. Walkowiak, Niezachowana dekoracja pictura graeca kościoła klasztoru benedyktynów na Łysej Górze. Późnośredniowieczna opowieść o przeszłości Królestwa Polskiego, in: In principio. Mit i prawda poczatku w kulturze polskiej i europejskiej. Materiaty XXXVII Seminarium Mediewistycznego im. A. Kartowskiej-Kamzowej, Poznań 2016 [in printing]

62 M. Derwich, Benedyktyński klasztor, p. 441; Z. Piech, Monety, pieczęcie i herby w systemie symboli władzy Jagiellonów, Warszawa 2003, p. 263; K. Bracha, op. cit., p. 20.

63 M. Derwich, Pacyfikat koronacyjny królów polskich, 'Kwartalnik Historyczny' 1991, 98, 4, p. 15

64 M. Rożek, Polskie insygnia koronacyjne. Symbole władzy państwowej, Kraków 2011, pp. 68-70. 
Starnawska, a researcher studying the significance of the cult of relics in medieval Poland, considers the particle of the Holy Cross a part of the 'ideological foundations of the Kingdom of Poland' next to the relics of St. Adalbert of Prague and St. Stanislaus. The story of the staurotheke, created in the late Middle Ages, was deliberately connected with the beginning of the Polish community and a new Christian order on these lands ${ }^{65}$.

The relationship between the graeco opere wall paintings and the political programme of Władysław Jagiełło is confirmed by iconographic research programmes conducted on the best preserved objects, i.e. the Holy Trinity Chapel in Lublin and the presbytery of the Sandomierz Cathedral. In this context, it is particularly important that research is now being conducted on the frieze with noble and royal coats of arms, an integral part of the graeco opere decoration of the cathedral presbytery, discovered recently during conservation works in the Sandomierz cathedral ${ }^{66}$.

For years, the picture of Władysław Jagiełło on a horse located in the Chapel of the Holy Trinity in Lublin has been recurring in the scientific debate. Marek Walczak has recently made a compelling interpretation of the image, claiming the picture is to present Jagiełło as 'the second Constantine the Great' ${ }^{67}$.

Taking all the issues and findings presented above into consideration, the presence of Byzantine paintings in the King's ceremonial bedroom in Wawel should be approached differently ${ }^{68}$. It was these ruined frescoes that

65 M. Starnawska, Świętych życie po życiu. Relikwie w kulturze religijnej na ziemiach polskich w średniowieczu, Warszawa 2008, pp. 528-529.

66 T. Giergiel, J. Ptak, Fryz heraldyczny odkryty w katedrze sandomierskiej, 'Rocznik Polskiego Towarzystwa Heraldycznego' serii nowej, 2011, 10 (21), pp. 3-36; M. Walkowiak, Dekoracja malarska zachodniego przęsta prezbiterium katedry w Sandomierzu. Scenografia królewskiego teatru władzy Władysława Jagietty, 'Zeszyty Sandomierskie' 2012, 33, pp. 5-18; M. Smorąg-Różycka, Bizantyńskie malowidła w prezbiterium katedry pw. Narodzenia Najświętszej Marii Panny w Sandomierzu - odkrycia niespodziewane i doniosłe, 'Modus. Prace z Historii Sztuki' 2013, vol. 12-13, pp. 53-72; idem, Bizantyńskie freski w sandomierskiej katedrze: królewski dar na chwałe Boża czy odblask idei unii horodelskiej?, 'Zeszyty Naukowe Uniwersytetu Jagiellońskiego, Prace Historyczne' 2014, 141, 2, pp. 235-255; T. Giergiel, J. Ptak, Heraldyczna interpretacja genezy i funkcji malowidet bizantyńsko-ruskich w prezbiterium kolegiaty sandomierskiej, 'Studia i Materiały Lubelskie' 2017, vol. 19, pp. 90-116.

67 M. Walczak, Portret konny króla Władysława Jagiełty w kaplicy Trójcy Świętej na zamku w Lublinie, in: Patronat artystyczny Jagiellonów, pp. 305-318; see also T. Trajdos, Treści ideowe wizerunków Jagiełty w kaplicy św. Trójcy na zamku lubelskim, 'Biuletyn Historii Sztuki' 1979, 41, 3, pp. 316-320; cf.: A. Różycka-Bryzek, Uwagi o referacie. M. Trajdosa, pp. 437-443; idem, Bizantyńsko-ruskie malowidła w kaplicy, pp. 122-124; M. Walkowiak, Na granicy królestw. Wędrowny teatr władzy króla Władysława Jagietty, in: Podróżnicy, fundatorzy, święci, ed. T. Ratajczak, Poznań 2008, pp. 70-76.

68 Rachunki dworu, pp. 202, 211. 
were usually invoked in publications propagating the idea about Jagiełło's personal predilection for Orthodox art ${ }^{69}$. Yet this decoration could not have been merely an ornament in the private space of the ruler. It is known that the royal bedrooms had important ceremonial functions in the late Middle Ages. Such was the case of the royal bedroom in Wawel ${ }^{70}$. I have interpreted the decoration of Władysław Jagiełło's dormitorium regis in a separate article. Using archaeological findings, I indicated the probable location of the bedroom in the late-medieval Wawel residence and analysed the significance of this place for the royal coronation ceremony ${ }^{71}$.

In late medieval Latin Europe, respect for the Byzantine tradition (in the broad sense) was not unique. In the late Middle Ages, references to the Byzantine Empire appeared in art commissioned by the royal courts of Central Europe and served to visualize their dynastic policy ${ }^{72}$. That might have been the ultimate motivation. Intensive contacts between the Polish, Czech and Hungarian Kingdom were conducive to adopting the models of presenting of the ideology of power ${ }^{73}$. Yet the main source of inspiration was probably the court of the Luxembourg royal family

69 In 1885, Marian Sokołowski wrote: ,[...] as he wanted to have these holy figures before his eyes, put against the blue backgrounds, looking all so solemn and awe-inspiring, he told them [the painters] to paint the sleeping chambers in Wawel in Byzantine style.'; see. M. Sokołowski, op. cit., p. 15; in the summary of the book on the paintings in the Holy Trinity Chapel in Lublin, Anna Różycka-Bryzek reflects on the reasons for employing Eastern painting masters in the Lublin chapel and other places in the Kingdom of Poland. As regards the Wawel bedroom, she writes: '[...] what could be greater than the desire to have direct contact with the art from his youth in the most intimate place'.; see A. RóżyckaBryzek, op. cit., p. 151.

70 A. Gieysztor, op. cit., p. 14; zob. też: Ordo coronandi regis Poloniae, ed. S. Kutrzeba, 'Archiwum Komisji Historycznej' 1909-1913, 11, pp. 148, 155, 161; P. Binski, The Painted Chamber at Westminster, London 1986; R.A. Jackson, Vive le Roi! A History of the French Coronations from Charles V to Charles X, London 1984, pp. 133-134.

${ }_{71}$ M. Walkowiak, Królewskie sny. Niezachowana dekoracja malarska wawelskiej sypialni Władysława Jagiełty, in: Odkrywanie świata w średniowieczu. Materiaty XXXV Seminarium Mediewistycznego im. A. Karlowskiej-Kamzowej, Poznań 2014 [in printing]

72 G. Szekely, Wegierskie symbole państwowe w dobie średniowiecza, ich zwiazki z Bizancjum oraz wartości ideowe, 'Kwartalnik Historyczny' 1988, 95, 4, pp. 21-33; E. Tóth, K. Szelényi, The Holy Crown of Hungary, Budapest 2015; S. Sroka, Wegry, Poznań 2015, pp. 111-126; J. Myslivec, Českágotica a Byzanc, 'Umění1970, 18, pp. 333-349; H. Belting, op. cit., pp. 381-382.

73 J. Kłoczowski, Młodsza Europa. Europa Środkowo-Wschodnia w kręgu cywilizacji chrześcijańskiej średniowiecza, Warszawa 1998; J. Dąbrowski, Korona Królestwa Polskiego w XIV wieku. Studium z dziejów rozwoju polskiej monarchii stanowej, Wrocław-Kraków 1956; J. Krzyżaniakowa, J. Ochmański, op. cit., pp. 140-351; P. Crossley, Bohemia Sacra and Polonia Sacra. Liturgy and history in Prague and Cracow Cathedrals, 'Folia Historiae Atrium' Seria nowa, 2001, 7, pp. 49-69; A. Fijałkowski, Średniowieczne koronacje królewskie na Węgrzech i w Polsce, 'Przegląd Historyczny' 1996, 87, 4, pp. 713-735. 
in Prague and the works funded by Emperor Charles IV ${ }^{74}$. Researchers studying his political ideology and artistic commissions have repeatedly underlined his interest in the past and in his particular fondness for the cult of the Holy Cross ${ }^{75}$. In the context of the issues discussed in this paper, it is important to review new studies on the way the Christian emperor at the Luxembourg court in Prague was building his image, based on the knowledge of the past, including his references to Constantine the Great. It sheds a new light on the commissions of Charles IV inspired by the art of ancient Rome ${ }^{76}$ and Byzantium, such as the mosaic of the Last Judgment above the southern portal of the St. Vitus cathedral. In the 14th century, a Czech chronicler Beneš Krabice of Weitmile described it with the term more Graecorum ${ }^{77}$. The Prague court of the Luxembourg era combined these efforts with the memory of the House of Přemyslid, native Czech rulers. The Luxembourgers saw themselves as the successors of the Premyslids. The combination of both these traditions gave rise to the Karlštejn Castle near Prague. It was the place where the most valuable treasures were kept, above all relics of the Passion and coronation insignia. The top floor of the castle tower houses the chapel of the Holy Cross, whose interior clearly refers to Byzantine temples but at the same time evokes the picture of Romanesque reliquaries ${ }^{78}$. The tympanum of one of the Karlštejn chapels presents the emperor and his wife Anna von Schweidnitz as a 'new' Saint Constantine and the 'new' Saint Helena. Charles and his wife are holding the crux gemmata, a symbol of Christ's triumph and a symbol of the imperial couple's participation in his power at the same time ${ }^{79}$. Another important commission of Charles, the Chapel of St. Wenceslas at the cathedral of St. Vitus in Prague, was created in a similar manner, i.e. by deliberately

74 R. Suckale, J. Fajt, The Example of Prague in Europe, in: Prague, pp. 47-57.

75 R. Chadraba, Profetický historismus Karla IV. A přemyslovská tradice, in: Karolus Quartus, Praha 1984, pp. 419-450; W. Iwańczak, Cesarz Karol IV i jego postawa wobec historii, in: Venerabiles, nobiles et honesti. Studia z dziejów społeczeństwa Polski średniowiecznej, eds. A. Radzimiński, A. Supruniuk, J. Wroniszewski, Toruń 1997, pp. 51-58; P. Crossley, op. cit.; B. Drake Boehm, Charles IV. The Realm of Faith, in: Prague, pp. 23-33.

${ }^{76}$ K. Kubínová, Imitatio Romae. Karel IV. a Řim, Praha 2006; idem, Karl IV. und die tradition Konstantins des Grossen, pp. 320-327; J. Fajt, op. cit., pp. 3-23.

77 Z. Všetečková, The Iconography of the Last Judgment Mosaic and Its Medieval Context, in: Conservation of the last Judgment Mosaic, St. Vitus Cathedral, Prague, eds. F. Piqué, D.C. Stulik, Los Angeles 2005, p. 21; M. Kostílková, The Last Judgment Mosaic: the historical record, 1370-1910, in: ibidem, p. 4; the contemporary condition of the mosaic is a result of multiple restoration procedures over the centuries, but the term used by the 14-th century chronicler refers to its initial, original design from the time of Charles IV; see Ibidem, p. 3-10.

78 Ibidem, p. 55; J. Fajt, op. cit., p. 13; H. Belting, op. cit., p. 381.

79 R. Chadraba, Kaiser Karls IV. Devotio antiqua, 'Mediaevalia Bohemica' 1969, 1, pp. $51-$ 68; J. Fajt, J. Royt, L. Gottfried, The Sacred Halls of Karlštejn Castle, Prague 1998, p. 16. 
archaizing the architectural form. Paul Crosley characterised the interior of the Chapel of St. Wenceslaus with the term Italo-Byzantine Romanism with early Christian elements ${ }^{80}$. He believes that the combination of different artistic styles which refer to distant historical periods and areas, visible in the commissions of Charles IV, is an example of him using art (contrary to the principle of stylistic uniformity) in order to recall the ideas or characters from the past that the Emperor needed in order to fulfil his overarching goal, i.e. to legitimise his power ${ }^{81}$. Conjuring the art of the Byzantine Empire, together with works representing various other traditions and places, created the image of a Christian emperor ${ }^{82}$.

The analogies between the commissions of Emperor Charles IV and graeco opere painted on the initiative of Władysław II in the Kingdom of Poland are not accidental. Among the advisors of the Polish King and experts operating in the royal chancellery were graduates of the University of Prague and people who gained their political experience at the Luxembourg court in that city ${ }^{83}$. It should be noted that there was a significant temporal coincidence of seemingly unrelated events. Source information shows that the first graeco opere made for Jagiełło in the Kingdom of Poland date back to the years 1393-1394. $4^{84}$ In 1393, according to Jadwiga Krzyżaniakowa, the royal chancellery of Władysław Jagiełło underwent 'a general reorganization'. The Luxembourg chancellery in Prague served as a model of operation, which probably, according to the scholar, should be connected with the first term of office of Mikołaj of Kurów, a graduate of the University of Prague and a close associate of Jagiełło $^{85}$. It is highly probable that other models from that environment

80 P. Crossley, The Politics of Presentations, pp. 101-102; see also P. Crossley, Z. Opačić, Prague as a New capital, in: Prague, p. 68.

81 P. Crossley, op. cit., pp. 99-112.

82 M. Bartlová, Ikon-like Images in Bohemian Medieval Art, 'Ikonotheka' 2009, 22, pp. 15 32; J. Myslivec, op. cit.; zob. też, I. Rosario, op. cit., pp. 9-10, 40-46; Hans Belting, in his texts on the Czech depictions of Madonnas created in the period of rule of Luxembourg dynasty, points out that the images were thought to possess the miraculous qualities of the original icons, whose patterns they replicated, zob. H. Belting, op. cit., pp. 381-386, 398.

83 H. Ożóg, Uczeni w monarchii Jadwigii Andegaweńskiej $i$ Władysława Jagiełty, Kraków 2004, pp. 27-33;

84 Rachunki dworu, pp. 202, 211.

85 In the years 1393-1399, Mikołaj of Kurów was a protonotary in the royal chancellery of Władysław Jagiełło and contributed to its reorganisation. Describing his role, Jadwiga Krzyżaniakowa wrote: it is very likely that he was particularly interested in rhetoric and epistolography while studying at university, and that he became acquainted with the organisation of the Czech chancellery thanks to his Czech friends. Given the close relationship of both masters and students of the Prague univeristy with the imperial chancellery, this is highly probable.' See. J. Krzyżaniakowa, Wprowadzenie formuty relacji 
were used in shaping the image of the Polish ruler and using art for this purpose ${ }^{86}$. The use of various artistic 'languages' for the purpose of communicating the ideological message and emphasizing particular symbols required to legitimise the client's power was one of the important achievements of the reign of Charles IV of Luxembourg. It perfectly fit the needs of Władysław Jagiełło, preoccupied with building his position.

\section{REFERENCES}

\section{Printed sources}

Damalewicz S., Series archiepiscoporum Gnesnensium, Varsaviae 1649.

Dlugossi J., Annales seu Cronicae incliti Regni Poloniae, lib. XI et XII, Varsaviae 2001.

Dlugossi J., Liber beneficiorum dioecesis Cracoviensis, vol. 1-3, ed. A. Przeździecki, Cracoviae 1863-1864.

Ostroróg J., Mowa wobec papieża Pawła II, in: 'Wybór mów staropolskich', ed. B. Nadolski, Wrocław 1961.

Rachunki dworu króla Władystawa Jagietty i królowej Jadwigi (1388-1420), ed. F. Piekosiński, Kraków 1896.

Stownik łaciny średniowiecznej w Polsce, vol. VII, 8, ed. K. Weyssenhoff-Brożkowa, Kraków 1998.

Stanisław ze Skarbimierza, Mozyy wybrane o madrości, ed. M. Korolko, Kraków 2000.

Zbiór dokumentów małopolskich, eds. I. Sułkowska-Kurasiowa, S. Kuraś, part 7, Wrocław 1975.

\section{Studies}

Baczkowski K., Argument obrony wiary w stużbie dyplomacji polskiej w XV wieku, in: Polska i jej sąsiedzi za Jagiellonów, ed. K. Baczkowski, Kraków 2012.

Baczkowski K., 'Panowie przyrodzeni' a elekcyjność tronu w Polsce średniowiecznej, in: K. Baczkowski, Polska i jej sąsiedzi za Jagiellonów, Kraków 2012.

Smorąg-Różycka M., Bibliografia prac Anny Różyckiej-Bryzek, in: Ars Graeca Ars Latina. Studia dedykowane prof. Annie Różyckiej-Bryzek, ed. M. Smorąg-Różycka, Kraków 2001.

do polskiej kancelarii królewskiej, in: Europa - Stowiańszczyzna - Polska. Studia ku uczczeniu profesora Kazimierza Tymienieckiego, eds. J. Bardach et. al., Poznań 1970, pp. 405-407; see also: idem, Kancelaria królewska Władysława Jagiełty, vol. 1, p. 25; the reorganisation process of Władysław Jagiełło's power base became noticeable in 1393, as was recently pointed out by Dariusz Wróbel. In this period, he notes, ,it can be concluded that the monarch took steps aimed at gaining the support of the nobility. He also intensified his efforts to create a stable base for his reign [...]. Wróbel continues, , we may assume that he aimed to advance the consolidation process by entrusting the actual management of the chancellery to Mikołaj of Kurów, who was henceforth a member of the monarch's closest associates', see D. Wróbel, op. cit., pp. 88-89; among graduates of the Prague University was Stanisław of Skarbimierz, another close associate, expert and adviser to the king, see K. Ożóg, Stanistaw ze Skarbimierza - uczony w stużbie Królestwa, pp. 70-71.

86 R. Suckale, J. Fajt, op. cit., pp. 47-57; Jerzy Grygiel argues there were 'multiple' benefits of Jagiełło's diplomatic contact with the Czech Kingdom in the mid-1390s, see. J. Grygiel, Polska a Czechy w dobie bitwy grunwaldzkiej, in: Bitwa grunwaldzka w historii, pp. 39-40. 
Bartlová M., Ikon-like Images in Bohemian Medieval Art, 'Ikonotheka' 2009, 22.

Belting H., Obraz i kult. Historia obrazu przed epoka sztuki, transl. T. Zatorski, Gdańsk 2010.

Biedrowska-Ochmańska K., Ochmański J., Władysław Jagiełło w opiniach swoich wspótczesnych. Próba charakterystyki jego osobowości, Poznań 1987.

Binski P., The Painted Chamber at Westminster, London 1986.

Borkowska U., Dynastia Jagiellonów w Polsce, Warszawa 2011.

Borkowska U., Codzienny i odświętny ceremoniat religijny na dworze Jagiellonów, in: Theatrum ceremoniale na dworze książąt i królów polskich, eds. M. Markiewicz, R. Skowron, Kraków 1999.

Borsook E., Messages in Mosaic. The Royal Programmes of Norman Sicily 1130-1187, New York 1990.

Bracha K., Kult relikwii Krzyża św. i pielgrzymka Władysława Jagietty do opactwa tysogórskiego w czerwcu 1410 r., in: Bitwa grunwaldzka w historii, tradycji i kulturze 1410-2010, ed. T. Ossowski, Kielce 2010.

Caro J., Aus der Kanzlei Kaiser Sigismundus. Urkundliche Beiträge zur Geschichte des Constanzer Concils, 'Archiv für Österreichische Geschichte' 1880, 59.

Chadraba R., Tradice druhégo Konstantina a řecko-perská antiteze v uměni Karla IV, 'Uměni' 1968, 16.

Chadraba R., Kaiser Karls IV. Devotio antiqua, 'Mediaevalia Bohemica' 1969, 1.

Chadraba R., Profetický historismus Karla IV. A přemyslovská tradice, in: Karolus Quartus, Praha 1984.

Crossley P., The Politics of Presentation. The Architecture of Charles IV of Bohemia, in: Courts and Regions, eds. R. Marks, A. Minnis, York 2000.

Crossley P., Bohemia Sacra and Polonia Sacra. Liturgy and history in Prague and Cracow Cathedrals, 'Folia Historiae Atrium' Seria Nowa, 2001, 7.

Crossley P., Opačić Z., Prague as a New capital, in: Prague. The Crown of Bohemia, 1347-1437, eds. B. Drake Boehm, J. Fajt, New York 2005.

Czechowicz B., Kapustka M., Hope and Pragmatism. The Rule and Visual Representation of Matthias Corvinus in Silesia and Lusatia, in: Matthias Corvinus, the King. Tradition and Renewal in the Hungarian Royal Court 1458-1490, Budapest 2008.

Dąbrowski J., Korona Królestwa Polskiego w XIV wieku. Studium z dziejów rozwoju polskiej monarchii stanowej, Wrocław-Kraków 1956.

Dalewski Z., Władza, przestrzeń, ceremoniat. Miejsce i ceremonia inauguracji władzy w Polsce średniowiecznej do końca XIV wieku, Warszawa 1996.

Dalewski Z., Ceremoniał hołdu lennego w Polsce późnego średniowiecza, in: Theatrum ceremoniale na dworze ksiażąt i królów polskich, eds. M. Markiewicz, R. Skowron, Kraków 1999.

Deptuła Cz., Z zagadnień relacji pomiędzy sztuka, polityka i programami unii kościelnej w państwie polsko-litewskim XV wieku, 'Summarum' 1995/1996, 24/25.

Derwich M., Działalność benedyktynów tysogórskich w XV wieku, 'Kwartalnik Historyczny' 1990, 3-4.

Derwich M., Pacyfikał koronacyjny królów polskich, 'Kwartalnik Historyczny' 1991, 98, 4.

Derwich M., Benedyktyński klasztor św. Krzyża na Łysej Górze w średniowieczu, WarszawaWrocław 1992.

Drelicharz W., Kolegiata wiślicka jako miejsce wizualnego dialogu monarchy ze społeczeństwem w XIV-XV wieku, in: Przeszłość jest czasem narodzin: z dziejów Wiślicy i jej związków z Krakowem, eds. A. Waśko, J. Smołucha, Kraków 2006.

Fajt J., Royt J., Gottfried L., The Sacred Halls of Karlštejn Castle, Prague 1998.

Fajt J., Charles IV. Toward a New Imperial Style, in: Prague. The Crown of Bohemia, 1347-1437, eds. B. Drake Boehm, J. Fajt, New York 2005.

Fałkowski W., Idea monarchii w Polsce za pierwszych Jagiellonów, in: Polska około roku 1400. Państwo, społeczeństwo, kultura, ed. W. Fałkowski, Warszawa 2001. 
Fałkowski W., Możnowładztwo polskie wobec króla, in: Kolory i struktury średniowiecza, ed. W. Fałkowski, Warszawa 2004.

Fałkowski W., Adventus regis. Powrót Władysława Jagiełty do Krakowa po zwycięstwie grunwaldzkim, 'Roczniki Historyczne' 2010, 76.

Fiałkowski A., Średniowieczne koronacje królewskie na Węgrzech i w Polsce, 'Przegląd Historyczny' 1996, 87, 4

Gąsiorowski A., Itinerarium króla Władysława Jagietty 1386-1434, corrected 2nd ed., supplemental material included, Warszawa 2015.

Gąsiorowski A., Podróże panującego w średniowiecznej Polsce, ‘Czasopismo Prawno-Historyczne' 1973, 25, 2.

Gąsiorowski A., Święta pańskie w praktyce objazdów króla Władystawa Jagiełty, in: Europa środkowa i wschodnia w polityce Piastów, ed. K. Zielińska-Melkowska, Toruń 1997.

Giergiel T., Ptak J., Fryz heraldyczny odkryty w katedrze sandomierskiej, 'Rocznik Polskiego Towarzystwa Heraldycznego' serii nowej, 2011, 10 (21).

Giergiel T., Ptak J., Heraldyczna interpretacja genezy i funkcji malowidet bizantyńsko-ruskich w prezbiterium kolegiaty sandomierskiej, 'Studia i Materiały Lubelskie' 2017, 19.

Gieysztor A., Spektakl i liturgia - polska koronacja królewska, in: Kultura elitarna a kultura masowa w Polsce późnego średniowiecza, Wrocław 1978.

Grabski A.F., Jadwiga - Wilhelm - Jagiełło w opiniach Europejskich, 'Nasza Przeszłość' 1966, 23.

Grygiel J., Polska a Czechy w dobie bitwy grunwaldzkiej, in: Bitwa grunwaldzka w historii, tradycji $i$ kulturze 1410-2010, ed. T. Ossowski, Kielce 2010.

Gryglewski P., De Sacra Antiquitate. Odwołania do przeszłości w polskiej architekturze sakralnej XVI wieku, Warszawa 2012.

Iwańczak W., Cesarz Karol IV i jego postawa wobec historii, in: Venerabiles, nobiles et honesti. Studia z dziejów społeczeństwa Polski średniowiecznej, eds. A. Radzimiński, A. Supruniuk, J. Wroniszewski, Toruń 1997.

Jabłoński J., Drzewo Żywota z Raju, Kraków: printed in the printing house of Jakub Matyszkiewicz 1737.

Jackson R. A., Vive le Roi! A history of the French coronations from Charles $V$ to Charles X, London 1984.

Jurkowlaniec G., West and East perspectives on the 'Greek Manner' in the Early Modern Period, 'Ikonotheka' 2009, 22.

Jurkowlaniec G., The Artistic Patronage of Ladislaus Jagietto. Beyond the Opposition between Byzantium and the Renaissance, in: Bizancjum a renesansy. Dialog kultur, dziedzictwo antyku. Tradycja i wspótczesność, ed. M. Janocha, Warszawa 2012.

Kajzer L., Gdzie w Sieradzkiem działali ruscy malarze Władysława Jagiełty? , ‘Kwartalnik Historii Kultury Materialnej' 2001, 4.

Kłoczowski J., Młodsza Europa. Europa Środkowo-Wschodnia w kręgu cywilizacji chrześcijańskiej średniowiecza, Warszawa 1998.

Koczerska M., Elita zjednoczonego Królestwa Polskiego w XIV-XV wieku i jej funkcja w państwie, in: Od genealogii do historii społecznej, eds. A. Jaworska, B. Trelińska, Warszawa 2011.

Kostílková M., The Last Judgment Mosaic: the historical record, 1370-1910, in: Conservation of the last Judgment Mosaic, St. Vitus Cathedral, Prague, eds. F. Piqué, D. C. Stulik, Los Angeles 2005.

Kowalczyk M., Mowa obediencyjna do antypapieża Jana XXIII, ‘Biuletyn Biblioteki Jagiellońskiej' 1996, 46.

Kowalski J., Gotyk wielkopolski. Architektura sakralna XIII-XVI wieku, Poznań 2010.

Krzyżaniakowa J., Wprowadzenie formuly relacji do polskiej kancelarii królewskiej, in: Europa Słowiańszczyzna - Polska. Studia ku uczczeniu profesora Kazimierza Tymienieckiego, eds. J. Bardach et. al., Poznań 1970. 
Krzyżaniakowa J., Kancelaria królewska Władysława Jagiełty. Studium z dziejów kultury politycznej Polski w XV wieku, vol. 1/2, Poznań 1972.

Krzyżaniakowa J., Polska - antemurale christianitatis - polityczne i ideologiczne podstawy ksztattowania się idei, in: Docendo Discimus. Studia historyczne ofiarowane Zbigniewowi Wielgoszowi w siedemdziesiata rocznice urodzin, eds. J. Kaczmarek, J. Nikodem, Poznań 2000.

Krzyżaniakowa J., Ochmański J., Władysław II Jagiełło, corrected 2nd ed., Wrocław 2006.

Kubínová K., Imitatio Romae. Karel IV. a Řim, Praha 2006.

Kubínová K., Karl IV. und die Tradition Konstantins des Grossen, in: Kunst als Herschaftsinstrumen. Böhmen und das Heiligerömische Reich unter den Luxemburgern im europäischen Kontext, Berlin-München 2009.

Kutzner M., Propaganda władzy w sztuce Zakonu Niemieckiego w Prusach, in: Sztuka w kreggu zakonu krzyżackiego w Prusach i Inflantach, ed. M. Wodniak, Toruń 1995.

Labuda A. S., Die architektonische Gestalt der Trinitäts - und der Heiligkreuzkapelle an der Krakauer Kathedrale im Kontextköniglischen Residenz auf dem Wawel, in: Die Länder der böhmischen Krone und Imre Nachbarn zur Zeit der Jagiellonenkönige (1471-1526). Kunst, Kultur, Geschichte, Ostfildern 2004.

Marsówna A., Freski ruskie w katedrze sandomierskiej, ‘Prace Komisji Historii Sztuki' 1930$1934,5$.

Mąkinia F., Ocena estetyczno-stylistyczna polskiej architektury w twórczości J. Długosza, 'Roczniki Humanistyczne' 1971, 19, 5.

Molè W., Kilka uwag o malowidłach ściennych w Wiślicy, 'Ochrona Zabytków Sztuki' 19301931, 1-4.

Molè W., Sztuka bizantyńsko-ruska 1040-1500, in: Historia sztuki polskiej, vol. 1, Kraków 1962.

Mrozowski P., Sztuka jako narzędzie władzy. Patronat artystyczny Kazimierza Wielkiego, in: Sztuka i wtadza. Materiaty z konferencji zorganizowanej przez instytut PAN w dniach 30.XI2.XII 1998, eds. D. Konstantynow et al., Warszawa 2001.

Mrozowski P., Sztuka jako narzędzie władzy królewskiej w Polsce, in: Dzieło sztuki: źródło ikonograficzne, czy coś więcej? Materiały sympozjum XVII Powszechnego Zjazdu Historyków w Krakowie, 15-18 września 2004, ed. M. Fabiański, Warszawa 2005.

Muczkowski J., Dwie kaplice jagiellońskie w katedrze krakowskiej, Kraków 1859.

Myslivec J., Českágotica a Byzanc, 'Umění' 1970, 18.

Nikodem J., Jadwiga. Król Polski, Wrocław 2009.

Olszacki T., Zamek królewski w Sieradzu. Dzieje - badania - architektura, Sieradz 2013.

Osieczkowska C., O szkole polskiej malarstwa bizantyńskiego, ‘Prace i materiały sprawozdań sekcji historii sztuki' 1935, 2.

Ożóg H., Uczeni w monarchii Jadwigii Andegaweńskiej i Władysława Jagiełty, Kraków 2004.

Ożóg K., Stanisław ze Skarbimierza - uczony w stużbie Królestwa Polskiego, in: Przeszłość jest czasem narodzin. Z dziejów Wiślicy i jej związów z Krakowem, eds. A. Waśko, J. Smołucha, Kraków 2006.

Ożóg K., Jagiellonowie a uczeni, in: Europa Jagiellonica 1386-1572. Sztuka, kultura i polityka w Europie Środkowej za panowania Jagiellonów. Materiały sesji zorganizowanej przez Zamek Królewski w Warszawie - Muzeum i Instytut Historyczny w Warszawie, eds. P. Mrozowski, P. Tyszka, P. Węcowski, Warszawa 2015.

Ożóg K., Miejsce i rola uczonych w późnośredniowiecznym pastwie polskim. Poglady mistrzów krakowskich a rzeczywistość, in: Genealogia. Władza i społeczeństwo w Polsce średniowiecznej, eds. J. Wroniszewski, A. Radzimiński, Torun 1999.

Piech Z., Średniowieczne herby w katedrze wawelskiej. Treści i funkcje, in: Katedra krakowska w średniowieczu, Kraków 1996.

Piech Z., Monety, pieczęcie i herby w systemie symboli władzy Jagiellonów, Warszawa 2003.

Pysiak J., Król i korona cierniowa. Kult relikwii we Francji Kapetyngów, Warszawa 2012. 
Podlacha W., Malarstwo średniowieczne, in: Historia malarstwa polskiego, vol. 1, Lwów 1914. Rosario I., Art and Propaganda: Charles IV of Bohemia, 1346-1378, Woodbridge 2000.

Rożek M., Polskie insygnia koronacyjne. Symbole władzy państwowej, Kraków 2011.

Różycka-Bryzek A., Malowidła ścienne bizantyńsko-ruskie, in: Malarstwo gotyckie w Polsce, vol. 1: Synteza, eds. A. Labuda, K. Secomska, Warszawa 2004.

Różycka-Bryzek A., Bizantyjsko-ruskie malowidła ścienne w Kaplicy Świętokrzyskiej na Wawelu (1470), 'Studia do Dziejów Wawelu' 1968, 3.

Różycka-Bryzek A., Zarys historyczny badań nad bizantyńsko-ruskimi malowidłami ściennymi w Polsce, 'Biuletyn Historii Sztuki' 1965, 27.

Różycka-Bryzek A., Uwagi o referacie T. M. Trajdosa pt. Treści ideowe wizerunków Jagiełty w kaplicy św. Trójcy na zamku lubelskim, 'Biuletyn Historii Sztuki' 1980, 42, 3/4.

Różycka-Bryzek A., Bizantyńsko-ruskie malowidła w kaplicy zamku lubelskiego, Warszawa 1983.

Różycka-Bryzek A., Niezachowane malowidła 'graeco opere' z czasów Władysława Jagiełty, 'Analecta Cracoviensa' 1987, 19.

Różycka-Bryzek A., Bizantyńsko-ruskie malowidła w Polsce wczesnojagiellońskiej. Problem przystosowań na gruncie kultury łacińskiej, in: Polska - Ukraina: 1000 lat sasiedztwa, vol. 2, ed. S. Stepień, Przemyśl 1994.

Różycka-Bryzek A., Freski bizantyńsko-ruskie fundacji Jagiełty w kaplicy zamku lubelskiego, Lublin 2000.

Smorąg-Różycka M., Bizantyńskie malowidła w prezbiterium katedry pw. Narodzenia Najświętszej Marii Panny w Sandomierzu - odkrycia niespodziewane i doniosłe, 'Modus. Prace z Historii Sztuki' 2013, 12-13.

Smorąg-Różycka M., Bizantyńskie freski w sandomierskiej katedrze: królewski dar na chwałe Boża czy odblask idei unii horodelskiej?, 'Zeszyty Naukowe Uniwersytetu Jagiellońskiego, Prace Historyczne' 2014, 141, 2.

Smorąg-Różycka M., Anna Cylejska - zapomniana patronka bizantyńskich malowideł w prezbiterium katedry pw. Wniebowzięcia Najświętszej Marii Panny w Sandomierzu, in: Patronat artystyczny Jagiellonów, eds. M. Walczak, P. Węcowski, Kraków 2015.

Sochacka A., Zjazdy polsko-litewskie w Lublinie i Parczewie w czasach Władysława Jagietty, in: A. Sochacka, Regimen - dominium - societas nobilium. Z dziejów gospodarki i polityki w Lubelskiem w średniowieczu, Lublin 2014.

Sochacka A., Powody lokalizacji w Lublinie grunwaldzkiego wotum Władysława Jagietty, in: A. Sochacka, Regimen-dominium - societas nobilium. Z dziejów gospodarki i polityki w Lubelskiem w średniowieczu, Lublin 2014.

Sokołowski M., Malarstwo ruskie, in: Wystawa archeologiczna polsko-ruska we Lwowie 1885 r., Lwów 1885.

Srodecki P., 'Schilt der Cristenheite i Scutum christianitatis' - spory polsko-krzyżackie a retoryka przedmurza/tarczy na początku XV wieku, in: Unia w Horodle na tle stosunków polsko-litewskich. Od Krewa do zaręczenia wzajemnego Obojga Narodów, ed. S. Górzyński, Warszawa 2015.

Sroka S., Węgry, Poznań 2015.

Sulimierska-Gąska A., At the crossroads of traditions. Ortodox church painting in the reign of the Jagiellons, 'Ikonotheka' 2009, 22.

Suckale R., Fajt J., The Example of Prague in Europe, in: Prague. The Crown of Bohemia, 13471437, eds. B. Drake Boehm, J. Fajt, New York 2005.

Starnawska M., Świętych życie po życiu. Relikwie w kulturze religijnej na ziemiach polskich w średniowieczu, Warszawa 2008.

Szekely G., Węierskie symbole państwowe w dobie średniowiecza, ich zwiazki z Bizancjum oraz wartości ideowe, 'Kwartalnik Historyczny' 1988, 95, 4. 
Szczaniecki P. OSB, Benedyktyni polscy. Zbiór szkiców i opowiadań, Tyniec 1989.

Tóth E., Szelényi K., The Holy Crown of Hungary, Budapest 2015.

Trajdos T.M., Treści ideowe wizerunków Jagiełty w kaplicy św. Trójcy na zamku lubelskim, ‘Biuletyn Historii Sztuki' 1979, 41, 3.

Trajdos T.M., Treści ideowe i kręgi stylistyczne polichromii bizantyńskich w Polsce za panowania Władystawa II Jagietty (1386-1434), 'Zeszyty Naukowe Wydziału Humanistycznego Uniwersytetu Gdańskiego. Slawistyka' 1982, 3.

Trajdos T., Benedyktyni na Łyścu za panowania Wtadystawa II Jagietty (1386-1434), ‘Rocznik Historyczny' 1982, 48.

Všetečková Z., The Iconography of the Last Judgment Mosaic and Its Medieval Context, in: Conservation of the last Judgment Mosaic, St. Vitus Cathedral, Prague, eds. F. Piqué, D.C. Stulik, Los Angeles 2005.

Walczak M., Rzeźba architektoniczna w Małopolsce za czasów Kazimierza Wielkiego, Kraków 2006

Walczak M., Casimir the Great's Artistic Foundations and the Court art of the Luxembourgs, in: Kunst als Herrschaftsinstrument. Böhmen und das Heilige Römische Reich unter den Luxemburgenim Europäischen Kontext, eds. J. Fajt, A. Langer, Berlin-München 2009.

Walczak M., Power and History. The Past as a Means of Legitimacy a Ruler's Authority in the Court art of Fourteen Century Poland, 'Uměni' 2014, 62.

Walczak M., Patronat artystyczny Jagiellonów, in: Patronat artystyczny Jagiellonów, eds. M. Walczak, P. Węcowski, Kraków 2015.

Walczak M., Jagiellonowie a sztuka, in: Europa Jagiellonica 1386-1572. Sztuka, kultura i polityka w Europie Środkowej za panowania Jagiellonów. Materiały sesji zorganizowanej przez Zamek Królewski w Warszawie - Muzeum i Instytut Historyczny w Warszawie, eds. P. Mrozowski, P. Tyszka, P. Węcowski, Warszawa 2015.

Walczak M., Portret konny króla Władysława Jagiełty w kaplicy Trójcy Świętej na zamku w Lublinie, in: Patronat artystyczny Jagiellonów, eds. M. Walczak, P. Węcowski, Kraków 2015.

Walczak M., Wyposażenie ruchome kaplicy Świętokrzyskiej w katedrze na Wawelu. Przyczynek do badań nad pobożnościa Jagiellonów, in: Jagiellonowie i ich świat. Dynastia Królewska w drugiej połowie XV i w XVI wieku, Kraków 2015.

Walicki M., Malowidła ścienne kościoła św. Trójcy na zamku w Lublinie, 'Studia do Dziejów Sztuki w Polsce' 1930, 3.

Walkowiak M., Na granicy królestw. Wędrowny teatr władzy króla Władysława Jagiełty, in: Podróżnicy, fundatorzy, święci, ed. T. Ratajczak, Poznań 2008.

Walkowiak M., Dekoracja malarska zachodniego przęsła prezbiterium katedry w Sandomierzu. Scenografia królewskiego teatru władzy Władystawa Jagiełty, 'Zeszyty Sandomierskie' 2012, 33.

Walkowiak M., Królewskie sny. Niezachowana dekoracja malarska wawelskiej sypialni Władysława Jagiełty, in: Odkrywanie świata w średniowieczu. Materiaty XXXV Seminarium Mediewistycznego im. A. Karłowskiej-Kamzowej, Poznań 2014 [in printing]

Walkowiak M., Niezachowana dekoracja pictura graeca kościoła klasztoru benedyktynów na Łysej Górze. Późnośredniowieczna opowieść o przeszłości Królestwa Polskiego, in: In principio. Mit i prawda początku w kulturze polskiej i europejskiej. Materiały XXXVII Seminarium Mediewistycznego im. A. Karłowskiej-Kamzowej, Poznań 2016 [in printing]

Węcowski P., Działalność publiczna możnowładztwa małopolskiego w późnym średniowieczu. Itineraria kasztelanów i wojewodów krakowskich w czasach panowania Władystawa Jagiełty (1386-1434), Warszawa 1998.

Węcowski P., Polskie itineraria średniowieczne i nowożytne. Przegląd badań i propozycje badawcze, 'Studia Źródłoznawcze' 2000, 37. 
Węcowski P., Dwa przyczynki do piastowskiej legitymizacji władzy Jagiellonów. Imiona i liczebniki w tytulaturze polskich Jagiellonów, in: Świat średniowiecza. Studia ofiarowane Profesorowi Henrykowi Samsonowiczowi, eds. A. Bartoszewicz et al., Warszawa 2010.

Wixom W.D., Byzantine Art and the Latin West, in: The Glory of Byzantium. Art and Culture of the Middle Byzantine Era, A. D. 843-1261, eds. H.C. Evans, W.D. Wixom, New York 1997.

Wróbel D., Elity polityczne Królestwa Polskiego wobec problemu krzyżackiego w czasach Władystawa Jagietty, Lublin 2017.

Wyrozumski J., 55 lat badań nad krytyczna reedycją dziejów Polski Jana Długosza, 'Nauka' 2006, 2.

\section{STRESZCZENIE}

Z inicjatywy króla polskiego Władysława Jagiełły wykonano zespół bizantyńskich malowideł ściennych, które Jan Długosz określa w swoich dziełach terminami: graeco opere, pictura graeca lub sculptura graeca. Malowidła te powstały w miejscach o szczególnym polityczno-religijnym znaczeniu dla Królestwa Polskiego a bizantyńską dekorację malarską dostosowano w przemyślany sposób do wnętrz gotyckich. Naukowa refleksja poświęcona jagiellońskim polichromiom, prowadzona od przeszło 150 lat, nadal nie daje pełnej jasności co do przyczyn tej oryginalnej syntezy artystycznej. Ugruntowana w polskiej mediewistyce teza o prywatnych upodobaniach króla Władysława Jagiełły do malarstwa bizantyńskoruskiego, wydaje się przy obecnym stanie wiedzy o roli sztuki w średniowieczu, tezą nie przekonującą. W opinii autora prezentowanego tekstu, przedstawiony wyżej problem wymaga postawienia nowych pytań i odświeżenia perspektywy badawczej. Autor, w swoich badaniach, analizuje omawiane malowidła przez pryzmat królewskiej teologii politycznej i znaczenia sztuki w procesie kształtowania wizerunku późnośredniowiecznego monarchy. Korzystając z najnowszych badań i ustaleń historyków, postrzega króla Władysława Jagiełłę przede wszystkim jako skutecznego i sprawnego polityka, a nie miłośnika sztuki.

Słowa kluczowe: malowidła bizantyńsko-ruskie, graeco opere, Władysław Jagiełł, Jagiellonowie, sztuka Jagiellonów, patronat artystyczny Jagiellonów

\section{ABOUT THE AUTHOR}

Marcin Walkowiak - graduate of the Institute of Art History at the Adam Mickiewicz University in Poznań, Member of the Association of Art Historians. Currently a PhD candidate under the supervision of prof. Tadeusz Żuchowski Institute of Art History at the Adam Mickiewicz University in Poznań, working on a PhD dissertation on the importance of the graeco opere paintings in Władysław Jagieło's political programme. Research interests: relation between art and politics in the Middle Ages, medieval political theology. E-mail: marcinwalkowiak@poczta.fm. 